\title{
AN ANALYSIS OF STUDENTS INTEREST IN WRITING PROCEDURAL TEXT THROUGH COOKING ACADEMY GAME
}

\author{
Annisa Dwi Yanti Tito ${ }^{1}$, Odo Fadloeli ${ }^{2}$ \\ ${ }^{1}$ IKIP Siliwangi \\ ${ }^{1}$ annisadwiyantitito@student.ikipsiliwangi.ac.id, ${ }^{2}$ odofadh@gmail.com
}

\begin{abstract}
This research was aimed at finding out how the condition of students interest in writing procedural text by using Cooking academy game at Telkom Senior high School. As a student learning by ICT (Information and Communication Technology) becomes a fundamental requirement in determining quality and effectiveness of learning process. This research was conducted at eleven grade students at Telkom senior high school with 34 students as a sample. This research used a qualitative descriptive method. The data instruments were questionnaire and interview. The result showed that most of the students had difficulties in writing procedural text, they and needed a media for helping them in learning process. Based on the interview of the students Telkom senior high school interested in Cooking Academy game in writing procedural text, after doing Cooking Academy game their vocabulary became more varied and easier poured into a text and writing process became more interesting and enjoyable, they could used it anytime and anywhere.
\end{abstract}

Keywords: Analysis, Writing, Cooking Academy

\section{INTRODUCTION}

English in Indonesia as a foreign language has been taught in Junior high schools and Senior high school with the purpose of giving opportunities to the students to access science and technology, and also to strengthen international relationship. Indonesian students should comprehend English subject in four skills. Each skill consists of many kinds of concepts, including writing skill.

Writing activity is the latest skills masterd by the students after listening, speaking, and reading skills (Nurgiyantoro, 2010).Writing in second language becomes more difficult task for the students (Anwar \& Ahmed, 2016). Due to the fact that people speak more obviously than writing in their routines.

In k-13 curriculum, language subject is taught based on the text learning. Procedure text is one of the text that is studied. The aims of procedure text is to explain how to do or to make something clear (Kosasih, 2014). Writing is the most complicated language skill, involving a variety of other elements, including the ability to arrange thoughts and feelings using words in the form of sentences that are appropriate to the structure and rules of grammar (Akhadiah, Arsjad, \& Ridwan, 2012). Most of Senior High School students problems are hard to find the theme, main idea, lack vocabulary, than combine words into a cohern paragraph.

In the era of globalization, ICT (Information and Communication Technology) becomes a fundamental requirement in determining quality and effectiveness of learning process. ICT in 
education refers to the use of computer based communication that incorporates into daily classroom instructional process and teachers are seen as the key players in using ICT in their daily classroom in preparing students for the current digital era (Ghavifekr \& Rosdy, 2015). Nowdays teaching learning process in Curriculum 2013 use a Scientific Approach or a sciencebased approach, including teaching English. Scientific approach in teaching learning is a teaching oriented to develop the student's ability to solve the problem by using integrated inquiry activities which demand to have a critical thinking, creative, to increase the students understanding (Abidin, 2014). The five steps are observing, questioning, asociating, experimenting, and communicating.

\section{METHOD}

This research was conducted at Telkom Senior High school with 34 students as a sinple. It used the descriptive qualitative method that has the purpose to describe and help the reader to know what is happening in the environmwnt under observation, what is the viewpoint of participants who are in the background of the research and what kind of events or activities that occur in the researcher background (Emzir, 2012). The instruments that's used for collecting data in this research are :

1. Questionnaire

Questionnaire is the data collection technique in which the participant / respondent fills in a question or statement then after completing it completely returns it to the researcher. The questionnaire to be given is a number of questions To find out students responses to the media that have been given .

2. Interview

Interview survey, are form on which the reseacher record to answer the questions supplied by the participant in the study. The researcher asks a question form an interview guide, listen for the answers or observes behavior and records responses on the survey (Creswell, 2012). Interviews can be conducted in a structured or unstructured manner and can be done through face-to-face or telephone channel.

\section{RESULTS AND DISCUSSION}

\section{Results}

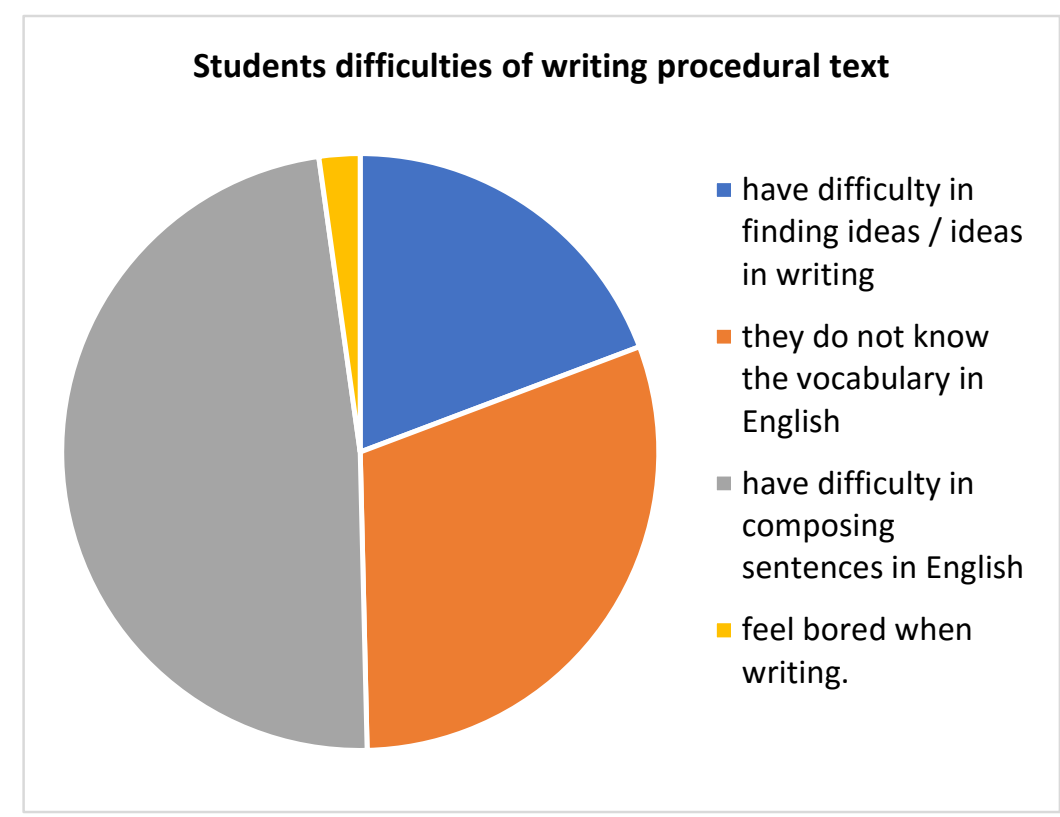


The researcher collected the data from the questionnaire and interview which was held at Telkom Senior High School with 34 students. In k-13 curriculum. Language subject is taught based on the text learning. Procedure text is one of the text that is studied. The aims of procedure text are to explain how to do or to make something clear (Kosasih, 2014) and writing is the most complicated language skills, involving a variety of other skills, including the ability to arrange thoughts and feelings using words in the form of sentences that are appropriate to the structure and rules of grammar (Akhadiah, Arsjad, \& Ridwan, 2012). Based on the interview, it was found that students of Telkom senior high school had some difficulties in writing procedul text, it was showed from the questionnaire. First, most of them have difficulty in composing sentences in English, then, that is equal to $41 \%$ students did not know the vocabulary in English with $26 \%$ hard to find the ideas in writing and felt bored also and $3 \%$ felt bored in writing English.

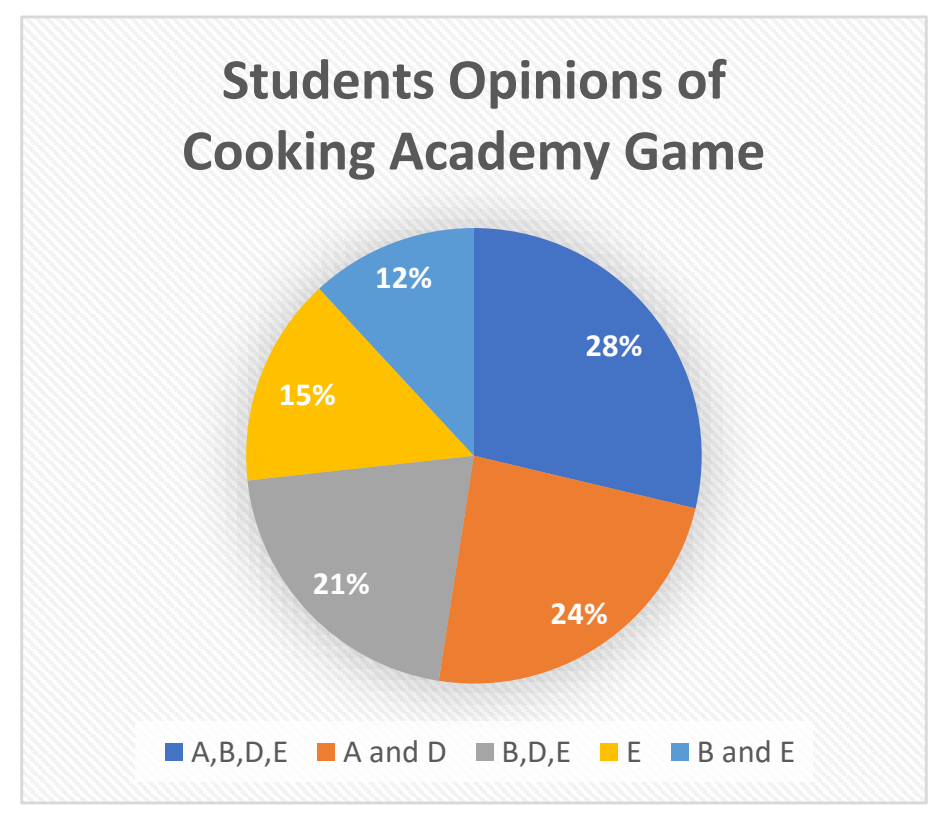

Cooking Academy games are categorised as computer-based media and learning activities with computers or better known as Computer Based Instruction (CBI) in general terms for all learning activities that use computers, either partially or as a whole (Arsyad, 2011). The questionnaire showed that Cooking Academy helped them in making procedural texts, with the opinions that $28 \%$ students said that Cooking Academy Game was very interesting, fun, make it easy to learn English, then $24 \%$ found that Cooking Academy Game was very interesting and made them easy to learn English, 21\% students said that it was a fun, made them easy to learn English and it was easy to use, $12 \%$ students though that Cooking Academy Game was fun and made them easy to learn English, and the rest argued that it was easy to use. After students played Cooking Academy Game they got lot of new vocabulary, a lot of and correct verb for writing procedural text, it was colourfull view made them easyly understand with the real picture which was made not bored and learning English more fun. Most of the students said that by using this media, the activity of writing texts in English becomes more interesting and fun, it can also be used anywhere. Then as much as $41 . \%$ argue that by using the media Cooking 
Academy 3 The vocabulary becomes more varied and more easily poured into English text and writing becomes more interesting and enjoyable when it can also be used anytime and anywhere and all of them said this teaching strategy was a fun, easy to understand,a lot of pictures and words were very helpful. They got a lot of vocabulary, the ideas and it made their writing procedure text get improved.

\section{CONCLUSION}

As students writing a procedural texts is a must according to the curriculum 13 English subject is taught based on the text learning, and procedure text is one of the texts that is studied. In this era globalisation ICT could helps learning process, and Cooking academy was categorised . According to the researcher, questionnaire showed that most of the students had difficulties in writing procedural text,then they needed a media for helping them in learning process. Based on the interview students of Telkom senior high school interested with Cooking Academy game in writing procedural text, the questionnaire show that after doing Cooking Academy game their vocabulary became more varied and easier poured into a text and writing process became more interesting and enjoyable that could be used anytime and anywhere.

\section{ACKNOWLEDGMENTS}

The highest gratitude and thanks to Allah SWT for giving us strength, health and motivation in finishing this. This article entitled "An Analysis Of Students Interest In Writing Procedural Text Through Cooking Academy Game is submitted as a final requirements at English Education Program, in IKIP Siliwangi Bandung. The writer says a lot of thank to everybody who supports us all this time, especially to Mr. Dr. H. Odo Padloeli, M. A. who guide us to write this article, and unforgettable to my colleagues who have support us in various ways.

\section{REFERENCES}

Abidin, Y. (2014). Desain Sistem Pembelajaran Dalam Konteks Kurikulum 2013. Bandung: PT Refika Aditama.

Akhadiah, S., Arsjad, M. G., \& Ridwan, S. H. (2012). Akhadiah, Sabarti dkk. 2012. Pembinaan Kemampuan Menulis Bahasa Indonesia. Jakarta: Erlangga.

Anwar, Muhammad Nadeem, and Nazir Ahmed. 2016. "Students ' Difficulties in Learning Writing Skills in Second Language." Science International (Lahore) 28(4): 735-39.

Arsyad, A. (2011). Media Pembelajaran. Jakarta: PT.Raja Grafindo Persada.

Creswell, j. (2012). Research Design Pendekatan Kualitatif, Kuantitatif, dan Mixed. Yogyakarta: Pustaka Pelajar.

Emzir. (2012). Metodologi Penelitian Kualitatif Analisis Data. Jakarta: Raja Grafindo.

Ghavifekr, Simin, and Wan Athirah Wan Rosdy. 2015. "Teaching and Learning with Technology: Effectiveness of ICT Integration in Schools." International Journal of Research in Education and Science 1(2): 175-91.

Kosasih. (2014). Jenis-Jenis Teks. Bandung: PENERBIT YRAMA WIDYA.

Nurgiyantoro, B. (2010). Penilaian dalam Pembealajaran Bahasa dan Sastra. Yogyakarta: BPFE. 